\title{
Penyuluhan Penggunaan Alat Peraga Rangkaian Listrik Sederhana bagi Guru- Guru SD Negeri 6 Mataram
}

\author{
Wahyudi $^{{ }^{*}}$, Muh. Makhrus ${ }^{1}$, I Wayan Gunada $^{1}$, Syahrial Ayub. $^{1}$, Muhammad Zuhdi ${ }^{1}$ \\ ${ }^{1}$ Program Studi Pendidikan Fisika, FKIP Universitas Mataram, Indonesia
}

DOI: https://doi.org/10.29303/jpmsi.v2i2.81

Citation: Wahyudi, W., Makhrus, M., Gunada, I. W., Ayub, S., Zuhdi, M. 2020. Penyuluhan Penggunaan Alat Peraga Rangkaian Listrik Sederhana bagi Guru-guru SD Negeri 6 Mataram. Jurnal Pengabdian Masyarakat Sains Indonesia (JPMSI). 2(2): 154-157.

Article history

Received: November $14^{\text {th }} 2020$

Revised: November $19^{\text {th }} 2020$

Accepted: November $23^{\text {th }} 2020$

*Corresponding Author:

Wahyudi, FKIP Universitas

Mataram, Mataram, Indonesia;

Email:wahyudi_arsi@unram.ac.id.

\section{Pendahuluan}

Ilmu Pengetahuan Alam (disingkat IPA) adalah pengetahuan yang sistematis dan tersusun secara teratur, berlaku umum, dan berupa kumpulan data hasil observasi dan eksperimen (Depdiknas, 2003). IPA adalah sebuah istilah yang merujuk pada rumpun ilmu di mana obyeknya adalah bendabenda alam dengan hukum-hukum yang pasti dan umum, berlaku kapanpun dan di manapun (Bramasti, R., 2012). IPA merupakan kumpulan pengetahuan dan proses. IPA sebagai proses merupakan langkah-langkah yang ditempuh para ilmuwan untuk melakukan penyelidikan dalam rangka mencari penjelasan tentang gejala-gejala alam.

Sedangkan Djoyosoediro menyatakan bahwa istilah Ilmu Pengetahuan Alam atau IPA dikenal juga dengan istilah sains, yang berasal dari bahasa Latin yaitu scientia yang berarti "saya tahu". Dalam bahasa Inggris, kata sains berasal dari kata science yang berarti "pengetahuan", yang berkembang menjadi social science (ilmu pengetahuan sosial, IPS) dan natural science (ilmu pengetahuan alam, IPA) (Djojosoediro, W., 2012).

Masih menurut Djoyosoediro, secara umum kegiatan dalam IPA berhubungan dengan eksperimen, walau dalam hal-hal tertentu, konsep IPA adalah hasil tanggapan pikiran manusia atas gejala yang terjadi di alam. Karena itu penggunana 
Wahyudi et al, Jurnal Pengabdian Masyarakat Sains Indonesia 2020, 2 (2):154-157. DOI : https://doi.org/10.29303/jpmsi.v2i2.81

alat peraga praktek menjadi sangat penting dalam pembelajaran IPA.

Untuk mempelajari IPA, yang diimplemetasikan dalam proses belajar-mengajar, guru harus memiliki strategi, agar peserta didik dapat belajar secara efektif dan efisien, mengena pada tujuan yang diharapkan (Roestiyah, 2001). Salah satu langkah untuk memiliki strategi itu ialah harus menguasai teknik-teknik penyajian, atau biasanya disebut metode mengajar.

Selain itu, diperlukan media yang berfungsi sebagai alat bantu mengajar, berkembang sedemikian pesatnya sesuai dengan kemajuan sains dan teknologi (Arsyad, 2009). Salah satu media yang digunakan dalam bahan ajar IPA adalah alat peraga praktik (APP) IPA, yang mempunyai peranan yang sangat penting dalam pembelajaran, yaitu untuk menjelaskan konsep, sehingga siswa memperoleh kemudahan dalam memahami hal-hal yang dikemukakan guru, memantapkan penguasaan materi yang ada hubungannya dengan bahan yang dipelajari, dan mengembangkan keterampilan (Anonim, 2011).

Hasil observasi awal di SD Negeri 6 Mataram, proses belajar mengajar masih didominasi oleh guru, dan guru tidak menggunakan media pembelajaran, walau ada yang menggunakan media, tetapi media tersebut tidak berfungsi secara efektif dan efisien. Hal ini sebagai salah satu penyebab kesulitan siswa dalam mempelajari mata pelajaran IPA SD. Padahal hasil penelitian menunjukkan bahwa penggunaan alat peraga praktek pada mata pelajaran IPA dapat meningkatkan hasil belajar siswa di SDN 06 Karang Tinggi (Ningsih, R. S., 2011).

Berdasarkan latar belakang di atas, maka perlu adanya suatu usaha agar guru-guru memiliki kemampuan menggunakan alat peraga praktek sederhana sebagai alat bantu untuk mempelajari pokok bahasan rangkaian listrik, yaitu melalui kegiatan: Penyuluhan Penggunaan Alat Peraga Praktek (APP) Rangkaian Listrik sederhana bagi Guru-guru SD Negeri 6 Mataram.

Tujuan dari kegiatan pengabdian ini adalah melatih guru-guru SD 6 Negeri Mataram dalam penggunakan alat peraga praktek rangkaian listrik sederhana. Sedangkan manfaat dari kegiatan pengabdian ini adalah sebagai berikut.
e-ISSN : 2715-2537

p-ISSN : 2715-2545

1. Meningkatkan keterampilan dan minat guru dalam menggunakan APP sederhana, hkhusunya rangkaian listrik.

2. Penggunaan APP rangkaian listrik sederhana dalam setiap proses belajar mengajar pada gilirannya akan meningkatkan hasil belajar siswa, khususnya dalam pokok bahasan rangkaian listrik.

\section{Metode Kegiatan.}

Pengabdian Masyarakat ini dilaksanakan dalam bentuk penyuluhan yang terdiri dari dua tahap yaitu: tahap pertama, penyuluhan cara menggunakan APP IPA sederhana tentang rangkaan listrik, dan tahap kedua, membimbing guru-guru SD praktek menggunakan APP IPA sederhana

Pada tahap penyuluhan, tim pengabdian masyarakat akan memberikan teori singkat yang berkaitan dengan rangkaian listrik sederhana di SD. Disela-sela penyuluhan, Tim pengabdian akan mempraktekkan cara mengunakan APP, diselingi dengan tanya jawab. Tahap berikutnya, guru dibagi menjadi 3 kelompok, dan setiap kelompok melakukan praktek penggunaan APP dibimbing oleh satu orang tim pengabdian masyarakat.

Selain membimbing peserta pelatihan, tim pengabdian juga melakukan evaluasi pelaksanaan kegiatan praktek penggunaan APP oleh guru. Tujuan dari evaluasi adalah memanfaatkan informasi yang diperoleh sebagai acuan dalam menentukan perlakuan selanjutnya. Evaluasi direncanakan dilakukan diakhir kegiatan dengan cara meminta kepada para peserta untuk mengungkapkan kesan dan pesan yang dirasakan setelah mengikuti kegiatan penyuluhan dan meminta peserta untuk memberi saran-saran dalam rangka kegiatan yang akan datang. Keberhasilan kegiatan ini dapat dilihat dari banyak sedikitnya aspek positif dan aspek negatif yang dikemukakan oleh peserta. Kelebihan dan kekuangan penggunaan APP akan menjadi evaluasi bagi pelaksanaan pengabdian tahun berikutnya.

\section{Hasil dan Pembahasan}

Pelaksanaan kegiatan penyuluhan dan penggunaan alat peraga pembelajaran (APP) IPA $\mathrm{SD}$ dengan topik rangkaian listrik dengan 
Wahyudi et al, Jurnal Pengabdian Masyarakat Sains Indonesia 2020, 2 (2):154-157. DOI : https://doi.org/10.29303/jpmsi.v2i2.81

menggunakan peralatan sederhana kepada guruguru SD Negeri 6 Mataram diaksanakan pada hari Senin, tanggal 9 Nopember 2020. Kegiatan penyuluhan dan penggunaan alat peraga pembelajaran (APP) IPA SD sederhana diikuti oleh 14 guru-guru SD Negeri 6 Mataram.

Berdasarkan hasil pengamatan, diskusi, dan wawancara kepada beberapa peserta penyuluhan secara acak diperoleh data bahwa kegiatan ini sangat bermanfaat bagi para peserta untuk memahami dan mempermudah dalam menggunakan alat peraga pembelajaran (APP) IPA sederhana, terutama rangkaian listrik seri paralel. Rangkaian seri paralel sederhana ini sangat bermanfaat untuk membantu guru-guru dalam melaksanakan proses belajar mengajar rangkaian listrik sederhana di sekoah dasar. Sebab alat peraga praktik (APP) seperti ini mempunyai peranan yang sangat penting dalam pembelajaran, yaitu untuk menjelaskan konsep, sehingga siswa memperoleh kemudahan dalam memahami hal-hal yang dikemukakan guru, memantapkan penguasaan materi yang ada hubungannya dengan bahan yang dipelajari, dan mengembangkan keterampilan.

Namun demikian ada beberapa guru yang mengalami kesulitan dalam membuat rangkaian seri dan paralel berdasarkan gambar rangkaian yang ada. Ketika ditunjukkan rangkaian listrik yang sudah jadi oleh tim pengabdian masyarakat, guruguru belum memahami apakah rangkaian itu termasuk rangkaian seri atau paralel atau gabungan seri-paralel. Kemudian oleh tim dijelaskan secara rinci, posisi baterai, jamper (kabel), bola lampu, dan saklar. Dengan mengetahui posisi baterai, jamper, bola lampu, dan saklar, dalam rangkaian, maka bisa diketahui jenis rangkaian itu, seri atau paralel atau gabungan keduanya. Agar lebih mudah, tim pengabdian menyarankan untuk membuat rangkaian yang persis dengan gambar yang ada. Dengan menggunakan teknik ini, dan selalu giat berlatih, niscaya permasalahan bisa diatasi.

Adapun beberapa penyebab kesulitan guru-guru dalam merangkai/membuat rangkaian listrik seri paralel yang sederhana ini karena selama ini mereka belum terbiasa menggunakan alat peraga pembelajaran dalam setiap kegiatan proses belajar mengajar. Mereka lebih suka menggunakan model ceramah, dan tanya jawab dalam melaksanakan kegiatan proses belajar mengajar di kelas. Karena itu kegiatan yang dilakukan oleh tim pengabdian
e-ISSN : 2715-2537

p-ISSN : 2715-2545

masyarakat program studi pendidikan fisiska FKIP Universitas Mataram ini sangat bermanfaat bagi guru-guru SD Negeri 6 Mataram.

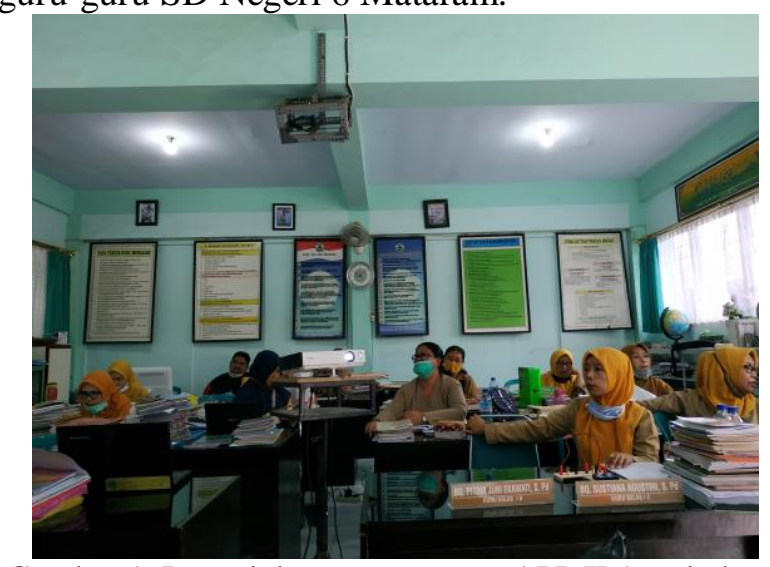

Gambar 1. Penyuluhan penggunaan APP IPA sederhana

Para peserta berharap agar kegiatan pengabdian seperti ini dapat dilakukan secara rutin dengan materi yang berbeda, terutama tentang penggunaan alat peraga pembelajaran yang lain yang bisa dibuat sendiri, misalnya dengan memanfaatkan barang-barang yang tidak terpakai di sekitar kita. Dengan menggunakan alat peraga pembelajaran dalam setiap proses belajar mengajar, secara tidak langsung guru-guru membiasakan peserta didik untuk belajar mengamati, menulis data hasil pengamatan, diskusi kelompok, dan diskusi antara kelompok serta belajar menarik kesimpulan.

\section{Kesimpulan}

Berdasarkan hasil observasi selama kegiatan berlangsung, termasuk tanya jawab, diperoleh informasi, yaitu materi yang disampaikan dalam kegiatan pengabdian ini sangat menarik, karena terdapat hal baru bagi peserta dalam mempelajari rangkaian listrik, yaitu menggunakan bahan-bahan yang sederhana, sehingga proses belajar mengajar menjadi lebih mudah, menarik, efektif dan efisien.

\section{Saran}

Peserta mengusulkan kegiatan pengabdian seperti ini sebaiknya dijadikan kegiatan rutin dengan materi yang berbeda dan durasi waktu yang lebih lama. Kegiatan ini diharapkan bisa menginspirasi peserta untuk mengembangkan 
pembuatan alat peraga pembelajaran yang lain, terutama yang memanfatkan barang-barang di sekiatar kita.

\section{Ucapan Terima Kasih}

Penulis mengucapkan terima kasih kepada Universitas Mataram melalui Lembaga Penelitian dan Pengabdian kepada Masyarakat (LPPM) yang telah membiayai kegiatan pengabdian ini. Selain itu, ucapan terima kasih juga disampaikan kepada guru-guru SD Negeri 6 Mataram yang menjadi peserta dalam kegiatan ini.

\section{Daftar Pustaka}

Anonim. 2011. Pedoman Pembuatan Alat Peraga Fisika Sederhana untuk SMA. Direktorat pembinaan SMA. Direktorat Jenderal Pendidkan Menengah Kemendikbud.

Arsyad, Azhar. 2009. Media Pembelajaran, Jakarta: Rajawai Pers.

Bramasti, R. 2012. Kamus Fisika. Surakarta: Aksarra Sinergi Media

Depdiknas. (2003). Kurikulum 2004, Standar Kompetensi Mata Pelajaran Sains Sekolah Dasar dan MI. Jakarta: Depdiknas.

Djojosoediro, W. (2012). Pengembangan Pembelajaran IPA SD. [electronic version] Surabaya: PGSD Unesa.

Ningsih, Rachma Suprapti. 2011. Problematika Pembelajaran IPA Kelas V Materi Peredaran Darah Manusia di Sekolah Dasar Gugus III Kecamatan Pakisaji Kabupaten Malang, Skripsi. Program Studi PGSD FIP, Universitas Negeri Malang : Malang (Tidak Dipublikasikan).

Roestiyah, 2001, Strategi Belajar Mengajar, Rineka Cipta : Jakarta. 